\title{
edoc
}

Institutional Repository of the University of Basel

University Library

Schoenbeinstrasse 18-20

CH-4056 Basel, Switzerland

http://edoc.unibas.ch/

\section{Insufficient evidence of Jatropha curcas L. invasiveness: experimental observations in Burkina Faso, West Africa}

Negussie, Aklilu and Nacro, Souleymane and Achten, Wouter and Norgrove, Lindsey and Kenis, Marc and Hadgu, Kiros Meles and Aynekulu, Ermias and Hermy, Martin and Muys, Bart

Posted at edoc, University of Basel

Official URL: http://edoc.unibas.ch/dok/A6308513

Originally published as:

Negussie, Aklilu and Nacro, Souleymane and Achten, Wouter and Norgrove, Lindsey and Kenis, Marc and Hadgu, Kiros Meles and Aynekulu, Ermias and Hermy, Martin and Muys, Bart. (2014) Insufficient evidence of Jatropha curcas L. invasiveness: experimental observations in Burkina Faso, West Africa. BioEnergy research, 16.10.2014, $11 \mathrm{~S}$. 


\section{Insufficient evidence of Jatropha curcas L. invasiveness: experimental observations in Burkina Faso, West Africa}

Aklilu Negussie ${ }^{1,2, *}$, Souleymane Nacro ${ }^{3}$, Wouter M.J. Achten ${ }^{4}$, Lindsey Norgrove ${ }^{5}$, Marc Kenis $^{6}$, Kiros Meles Hadgu ${ }^{2}$, Ermias Aynekulu ${ }^{7}$, Martin Hermy ${ }^{1}$ and Bart Muys ${ }^{1 *}$

${ }^{1}$ Division Forest, Nature and Landscape, KU Leuven, Celestijnenlaan 200E-2411, Belgium

${ }^{2}$ World Agroforestry Center (ICRAF), P.O.Box 5689, Addis Ababa, Ethiopia

${ }^{3}$ Fondation Fasobiocarburant, BP 200 Léo, Burkina Faso

${ }^{4}$ Institute for Environmental Management and Land Use Planning (IGEAT), Université Libre de Bruxelles (ULB), Avenue Antoine Depage 13, 1050 Brussels, Belgium.

${ }^{5}$ Department of Environmental Sciences (Biogeography), University of Basel, St Johanns Vorstadt 10, CH-4056 Basel, Switzerland

${ }^{6} \mathrm{CABI}$, Rue des Grillons 1, CH-2800 Delémont, Switzerland

${ }^{7}$ World Agroforestry Centre (ICRAF), United Nations Avenue, P.O.Box 30677-00100, Nairobi, Kenya

*Corresponding author

E-mail addresses: aklilumekuria@gmail.com; snacro2006@yahoo.fr; wouter.achten@ulb.ac.be; lindsey.norgrove@unibas.ch; m.kenis@cabi.org; K.Hadgu@cgiar.org; e.betemariam@.cgiar.org; Martin.Hermy@ees.kuleuven.be; Bart.Muys@ees.kuleuven.be

\section{*Corresponding authors}

Dr. Aklilu Negussie

Address: World Agroforestry Center, P.O.Box 5689, Addis Ababa, Ethiopia; e-mail: aklilumekuria@gmail.com

(Aklilu Negussie)

Prof. Dr. Ir. Bart Muys

Address: Celestijnenlaan 200E-2411, BE-3001 Leuven, Belgium. Tel. +32-16-329721 fax: +32-16-329760; e-mail: bart.muys@ees.kuleuven.be (Bart Muys)

Type of paper: original research paper 


\begin{abstract}
Biofuel plants such as Jatropha curcas L. have potential to support the livelihoods of rural communities and contribute to sustainable rural development in Africa, if risks and uncertainties are minimized. Yet recent papers have warned of the risk of biological invasions in such tropical regions as a consequence of the introduction of exotic biofuel crops. We investigated the seed dispersal risk and invasiveness potential of both $J$. curcas monoculture plantations and live fences into adjacent cultivated and uncultivated land use systems in Sissili province, Burkina Faso. Invasiveness potential was assessed through (i) detecting evidence of natural regeneration in perimeters around $J$. curcas plantations and live fences, (ii) assessing seed dispersal mechanisms and (iii) assessing seedling establishment potential through in situ direct seed sowing. Spontaneous regeneration around the plantation perimeters of the three sites was very low. Individual seedling density around $J$. curcas live fences was less than $0.01 \mathrm{~m}^{-2}$ in all sites. Seventy percent of the seedlings were found close to the live fence and most of them derived from the same year (96\%), which indicates low seed-bank longevity and seedling survival. Jatropha curcas can be dispersed by small mammals and arthropods, particularly rodents and ants. In some sites, such as in Onliassan, high secondary seed dispersal by animals (up to 98\%) was recorded. There were highly significant differences in germination rates between seeds at the soil surface (11\%) and those buried artificially at $1-2 \mathrm{~cm}$ depth $(64 \%)$. In conclusion, we failed to find convincing evidence of the spreading of $J$. curcas or any significant impact on the surrounding environment.
\end{abstract}

Key words: biofuel, seed dispersal, regeneration ecology, land use, Africa

\title{
Introduction
}

Agrobiofuels have been considered as a possible means of securing future energy supplies at lower environmental cost [1]. Biofuels derived from agricultural crops may reduce reliance on fossil fuels and mitigate greenhouse gas emissions [2]. Approximately $75 \%$ of the world's total $\mathrm{CO}_{2}$ emission is associated with the burning of fossil fuel [3]. In addition, increasing rates of fossil fuel consumption may lead to fossil fuel exhaustion in less than 100 years [4]. However, any alternative energy must be technically feasible, economically competitive, readily available and environmentally acceptable [1]. To date, the production of biofuel such as palm oil has been associated with both agricultural intensification and expansion, major drivers of habitat modification and a cause of biodiversity loss [2]. 
Equally, biological invasion by introduced new species is considered as one of the greatest threats to biodiversity and unwanted land use changes [5], occurring because of both deliberate and accidental introductions [6,7]. Biological invasions can threaten natural capital, ecosystem stability, and economic productivity and, as such, ecosystem and societal resilience [8].

The risk of biofuel plants becoming invasive has been discussed in recent papers [9-13]. Yet, few studies have sought to determine the invasiveness potential of biofuel species in the tropics and sub-tropics (e.g. $[12,14,15])$. To do so, it is necessary to consider their biological attributes, the current development and production pathway and social, economic and ecological risks. Therefore thorough invasiveness risk assessment of currently cultivated biofuel crops (e.g. Jatropha curcas L.) should be a priority task in the conservation of those tropical ecosystems.

To assess the invasiveness risk of plants, three broad approaches have been used: quantitative statistical models [16,17], semi-quantitative scoring systems $[18,19]$ and experimental approaches for field assessment $[12,20]$. Ecological risk assessments through in situ field experimental researches are considered effective at assessing the invasiveness risk of biofuel crops in the field $[12,13,20]$. This in situ field-based invasiveness evaluation approach may also help to regulate and design adaptive management strategies and mitigations in the cultivation of those currently adopted biofuel crops [21,22].

Jatropha curcas L. (Euphorbiaceae) is a small tree or shrub with a life span of about 50 years [23]. It has oily seeds, which are considered as a feedstock for biodiesel production and, as such, a considerable promise for a bio-based economy [23-26]. According to Brittaine and Lutaladio [27] and Nassiré Derra et al. [28], J. curcas is believed to have been spread in the 16th century by Portuguese seafarers from its centre of origin in Central America and Mexico via Cape Verde and Guinea Bissau (West Africa) to other countries in Africa and Asia. It is now widespread throughout the tropics and sub-tropics. In West Africa (e.g. Cape Verde Islands, Mali, Burkina Faso, Senegal, Ghana, Ivory Coast, Nigeria and Cameroon), J. curcas has been used for generations as a 'living fence', protecting food crops against animals, providing bee forage and reducing soil erosion, if carefully planted [29]. Traditionally, the seeds were also collected by women and used for medical treatments, lamp oil and soap making [30]. It was also an export crop, at one time representing $60 \%$ of the total value of agricultural exports in Cape Verde [30]. The plant has been widely utilized nationwide in Burkina Faso at least for the last 300 years. At present, due to the increasing 
popularity of the species, there is a strong pressure to intensify cultivation in tropical and subtropical regions including West Africa $[13,31]$. However, reports have mentioned the risk of invasion and associated damage as a result of land use conversion to $J$. curcas plantations $[9,15,17,32,33]$.

Different countries have different perspectives on the potential invasiveness risk of $J$. curcas. Australia [32,35], some of the Pacific Islands [32,38,39], India (in Chandigarh, Chhattisgarh and Dadra and Nagar Haveli regions) [37] as well as the islands of Hawaii, USA [15,37], and the Galapagos of Ecuador [32,39], consider $J$. curcas to be potentially invasive so the establishment of new fields has been prohibited.. Some other Asian and sub-Saharan African countries, with the exception of South Africa where it has been banned [34,36], still consider planting $J$. curcas [40-43]. Findings of high risk in other locations reflect a high probability that $J$. curcas could become naturalized in those areas, based on a widely recognized Weed Risk Assessment (WRA) system [18,19,44]. Some of the regions mentioned above are characterized by a tropical wet climate [45]. In these regions, the species might flower and seed twice per year, thus increasing the probability of a higher seed production and subsequent invasiveness. The other explanation is that ecological traits of the species could vary geographically as a result of plasticity to habitat conditions where the plant species is introduced $[13,46]$.

Field observations in Africa (Zambia and Malawi) have demonstrated low primary and secondary seed dispersal, low germination and low seedling survival probability [12,13, Aklilu Negussie personal observation]. The seeds of $J$. curcas are not reported to be effectively dispersed by conventional means, such as wind and water. It has been repeatedly mentioned in the literature that primary dispersal is mainly effected by humans and gravity $[12,47]$. Jatropha curcas seeds or fruit can be transported by water but the probability of germination under waterlogged conditions might be low, since $J$. curcas seedlings are susceptible to water logging, associated with low oxygen around the root zone of the germinated seedling $[48,49]$. A spontaneous regeneration assessment study in Zambia [12] revealed that the occurrence of $J$. curcas populations outside plantation boundaries is very unlikely. Fruits dropped through gravity were concentrated largely under the canopy of the parent plant, within an average radius of $0.79 \pm 0.51 \mathrm{~m}$ from the parent stem [12]. Secondary seed dispersal can be effected by mammals, such as rodents and shrews, sometimes up to a distance of $23 \mathrm{~m}$ from the sources [12].

The cultivation of $J$. curcas in Burkina Faso occupies approximately $5 \%$ of the arable lands but much of this is in the 
form of live fence [28]. Recent studies have revealed that between 2011 and 2012, 10,000 hectares of $J$. curcas were planted in the country [50]. Thus, while there is presently no report of $J$. curcas being invasive in West Africa, it cannot be ruled out that the dramatic increase in $J$. curcas plantations and, subsequently, in propagule pressure will modify the invasive risk potential of the plant.

Despite the high importance of WRA conclusions $[18,19,44]$ in predicting the spreading risks of alien crops, WRAs need to be combined with ecological field experiments to reach reliable decisions, particularly in the context of bioenergy decisions $[13,51,52]$, which this study aims to provide empirical evidence to substantiate the widely recognized weed risk assessment models using field experiments. Quality ecological data from in situ ecological experiments and field surveys such as, current population size, seed production rate, seed size, dispersal ability, dispersal vectors, and after dispersal fate of the seeds would be important data in establishing the future invasion risk of potential alien tropical biofuel crops (Thompson \& Davis, 2011; Flory et al., 2012; Negussie et al., 2013). This is also the subject of many questions in WRA protocols. Using this quality field data in current WRA models could reduce uncertainties in the prediction of invasiveness risk of the investigated plant.

This paper analyses the invasiveness behaviour of $J$. curcas through in situ experimental field research in Burkina Faso, West Africa to provide valid information on the spreading and invasiveness potential of $J$. curcas. This is the first invasiveness study in West Africa although J. curcas was introduced more than 300 years ago. We evaluated the risk of seed dispersal and germination from $J$. curcas plantations and live fences to adjacent land use systems through natural and artificial methods (spontaneous regeneration, primary and secondary seed dispersal by small mammals and in situ seed germination experiments). The research will also provide a comparison with similar experiments carried out in a different environment in southern parts of Africa, Zambia [12].

\section{Materials and Methods}

\section{Study sites}

Experiments were conducted in the central west region of Burkina Faso, Sissili province (between $11^{\circ} 00^{\prime}$ to $11^{\circ} 55^{\prime}$ $\mathrm{N}$ and $1^{\circ} 34^{\prime}$ to $2^{\circ} 48^{\prime} \mathrm{W}$ ) with an average altitude of $320 \mathrm{~m}$ above sea level. Observations were made during the fruiting and seeding season of J. curcas in the region (between July 2012 and September 2012). In the province, two distinct seasons exist; a long rainy season (April to October) and a dry season between October and April. The area receives an average annual rainfall of $1000 \mathrm{~mm}$ with an average annual temperature of $28{ }^{\circ} \mathrm{C}$ (fig. 1). The 
hydrographic network of the province is made of small seasonal rivers that become dry during the long dry season. The majority of the soils are sandy, fine gravel and ferruginous as well as being shallow and poor. In some areas, the alluvial and sandy soils are fertile and deeper than the ferruginous and gravel soils. The Sissili province contains 32,700 ha of protected forest that shelters a diverse fauna. The vegetation in the area is predominately savannah type with most prominent tree species being: Butyrospermum parkii, Parkia biglobosa, Afzelia africana, Anogeissus leiocarpus, Pterocarpus erinaceus, Burkea africana, Asoberlinia doka, Tamarindus indica, Crossopteryx febrifuga, Adansonia digitata, and Combretum spp. There are also diverse types of grasses and sedges in the wetlands. Flowering and fruiting of $J$. curcas occurs during the wet season between May and October (fig. 1), as in other Sahelian countries within the same agroecozone e.g. Mali. Similarly, in the southern parts of Africa, which are also seasonally dry, it also flowers in the rainy season, which there is predominantly between November to April [54].

(Insert fig. 1)

Three sites (Tabou, Onliassan and Benaverou) were chosen for the controlled experiments (seed removal and natural vs. artificial seed germination experiments). The first site, Tabou $\left(11^{\circ} 23^{\prime} \mathrm{N}\right.$ and $\left.2^{\circ} 08^{\prime} \mathrm{W}\right)$, was located approximately $35 \mathrm{~km}$ north of Léo $\left(11^{\circ} 07^{\prime} \mathrm{N}\right.$ and $\left.2^{\circ} 04^{\prime} \mathrm{W}\right)$ the capital of the province. The second and third sites, Onliassan $\left(11^{\circ} 03^{\prime} \mathrm{N}\right.$ and $\left.2^{\circ} 12^{\prime} \mathrm{W}\right)$ and Benaverou (11 $03^{\prime}$ and $\left.2^{\circ} 09^{\prime} \mathrm{W}\right)$, were located about 15 and $10 \mathrm{~km}$ west of Léo, respectively. All the plantations were 4 years old, established in 2009 from seedlings raised in the nearby nurseries from seeds. All the plantations were planted at $2 \times 2 \mathrm{~m}$ spacing $\left(2500 \mathrm{plants} \mathrm{ha}^{-1}\right)$, rainfed, never pruned nor fertilized. To assess the seed dispersal risks and invasiveness potential from live $J$. curcas fences to the surrounding landuse systems, 8 sites (Kayero, Léo, Zoro, Metio, Yalle, Neboun, Tabou and Benaverou) were chosen from the same province with a $J$. curcas live fence history of 3-40 years old (live fences planted from 1972 to 2009).

\section{Natural regeneration occurrence}

Jatropha curcas plantations and live fences were identified in Sissili province to estimate their spreading risk to the surrounding ecosystems. Occurrence of new seedlings (from the current growing season) and old $J$. curcas seedlings (from previous growing seasons) were assessed in the J. curcas plantations and adjacent land use systems of Tabou, Onliassan and Benaverou. New seedlings can be differentiated by their soft light-green stem, presence of broad 
cotyledonary leaves and two soft primary leaves, which the old seedlings lack. In Tabou, the J. curcas plantation was 2.1 ha with adjacent open grassland (1 ha) and cultivated lands (mainly for groundnut, maize and millet) (4.5 ha). The $J$. curcas plantation at Onliassan was 1.04 ha and the adjacent land use systems were fragmented woodland (4.1 ha) and open grassland ( 3 ha). The third site Benaverou, the $J$. curcas plantation was 1.1 ha with adjacent land uses of croplands (4 ha) and open grassland (1 ha). The open grasslands were freely grazed, but during our seed removal experiment, livestock were excluded for 1 month to avoid damage to the experimental plots.

To estimate seedling density in each land use type, both plot and plotless sampling techniques were used. For all sites (Tabou, Onliassan and Benaverou), for each J. curcas plantation,, plot-based systematic grids with 25 $\mathrm{m}$ intervals and a plot size of $2 \times 2 \mathrm{~m}$ were laid out following a method adapted from Negussie et al. [12]. The first plot was chosen randomly. Seedling density was estimated in 35 (Tabou), 17 (Onliassan) and 24 (Benaverou) plots in the $J$. curcas plantations. Similarly, systematic grid plot sampling techniques (with $25 \mathrm{~m}$ intervals and a plot size of $2 \times 2 \mathrm{~m}$ ) were also used to assess seedling emergence in land uses adjacent to the $J$. curcas plantations, at all sites (Tabou, Onliassan and Benaverou). In total, 21 (for open grassland) and 58 plots (cropland) at Tabou; 60 (for fragmented woodland) and 23 (for open grassland) plots at Onliassan; and, 24 (open grassland) and 71 (for cropland) plots at Benaverou were assessed.

The systematic plots for adjacent land uses were established by considering the probability of occurrence of seed and seedling concentration within the first few metres distance of the boundaries of the plantations. The first systematic plot at each grid line was established immediately next to the boundary of the $J$. curcas plantation. In addition, plotless sampling techniques were used to assess seedling occurrences in adjacent land use types. For this, line transects perpendicular to $J$. curcas plantation were established towards the adjacent croplands, fragmented woodlands and open grasslands following Negussie et al. [12]. The transects were laid out at fixed intervals of $50 \mathrm{~m}$ up to the boundary limit of each land use system. The number and length of the transects depended on the size of each land use system. Sample points were taken every $50 \mathrm{~m}$ interval along each transect. At each transect sample point, the nearest $J$. curcas seedling was searched for and the distance between the transect point and seedling position was measured. A total of 7 transects with 31 points for fragmented woodlands (at Onliassan), 16 transects with 66 points for croplands ( 7 transects and 30 points for Tabou and 9 transects and 36 points for Benaverou) and 10 transects with 34 points for open grasslands (4 transects and 10 points for Tabou, 3 transects and 12 points for Onliassan and 3 transects and 12 points for Benaverou) were established to estimate seedling density per land use at each site. We used more than one transect line per land use system to increase our 
precision in estimating seedling density per each land use system. We also did a census survey on each adjacent land use for all sites to find individual seedlings.

Several live fences that had been established in 8 villages were used to estimate the invasiveness risk of $J$. curcas around the live fences. A total of $3.8 \mathrm{~km}$ length of transects were laid out to assess seed dispersal and germination probabilities of $J$. curcas live fences to the surrounding ecosystems. Transects were laid out parallel to the $J$. curcas live fence at a distance up to10 $\mathrm{m}$ from both sides of the live fence (one transect on each side). Sample points were taken every $10 \mathrm{~m}$ along each transect. The number of live fences, transects and sampling points, in parentheses, per village was as follows: Kayero, 7 live fences , 14 transects (206 points), Yalle 3 live fences, 6 transects (147 points), Neboun 3 live fences, 6 transects ( 82 points), Léo 4 live fences 8 transects (122 points), Zoro 3 live fences, 6 transects ( 86 points), Metio 6 live fences, 12 transects (152 points), Tabou 3 live fences 6 transects (91 points) and Benaverou 2 live fences, 4 transects (58 points). Most of the live fences were adjacent to cultivated lands, mainly for maize, groundnut and millet production, except the two hedges at Kayero (one side was cultivated land and the other side was open grassland).

Mean seedling densities in the $J$. curcas plantations were estimated on a per hectare basis by multiplying total individual seedlings counted in all plots by $10,000 \mathrm{~m}^{2}$ divided by the sampled plot area in $\mathrm{m}^{2}$ following Negussie et al [12]. For estimation of $J$. curcas seedlings adjacent to $J$. curcas plantations and $J$. curcas live fences, the closest individual plotless density estimator was used, based on the formula given in Engeman et al. [55]:

$$
B D C I=\frac{1}{4\left[\sum_{i=1}^{N} R 1(i) / N\right]^{2}}
$$

Where BDCI is the closest individual basic distance density estimator (individuals $\mathrm{m}^{-2}$ ), R1(i) is the distance from transect point $i$ to the closest $J$. curcas seedlings (m), and $\mathrm{N}$ is the number of sample points. 


\section{Seed dispersal experiment}

Experiments were established at three sites (Tabou, Onliassan and Benaverou), between 15 August 2012 and 17 September 2012, to assess secondary seed dispersal by animals after Aerts et al. [56] and Negussie et al. [12]. In each site, 48 seed-containing depots (each depot contained 10 seeds) were placed in J. curcas plantations and adjacent land use systems (fragmented woodlands and open grasslands). Depots were made from $2 \mathrm{~mm}$ hole size mesh (each depot size: $15 \mathrm{~cm} \times 15 \mathrm{~cm} \times 2.5 \mathrm{~cm}$ ). The remaining, intact seeds were counted after $1,3,6,9,12,15$, $18,21,24,27$ and 30 days. During the experiment, animal tracks and droppings containing seeds were recorded to identify the $J$. curcas seed-dispersing animals. To validate this, traps were placed in different land use systems to catch these animals alive. During the entire experimental period, observations were also carried out to identify primary fruit and seed dispersal by animals (e.g. avian dispersal).

For the seed removal experiment at each site, Friedman one-way ANOVA was performed to detect fruit removal differences between different land use systems, considering the probability that the same animal may remove seeds from some or all of the depots [56]. To compare seed removal in 3 sites, Kruskal-Wallis one-way ANOVA (KW) was performed. Seed survival was analysed using Kaplan-Meier survival analysis, which measures the time to an event for each case occurrence i.e. the time from offering the seeds in a depot, until the moment that all seeds were removed from the depot.

\section{In situ direct seed sowing experiment}

To estimate in situ seed germination success of dispersed seeds, J. curcas seeds were sown in different land use systems such as $J$. curcas plantations, open grasslands and fragmented woodlands at Tabou, Onliassan and Benaverou between 13 August 2012 and 20 September 2012. The method of sowing and the treatment design were as follows: at each site, seeds were either sown at 1-2 $\mathrm{cm}$ depth or distributed on the soil surface (to mimic natural dispersal) at randomly selected positions in 5 plots per land use system $(3$ sites $\times 3$ land uses/site $\times 5$ plots/land use $\times 10$ seeds/plot $\mathrm{x}$ buried or surface). Seeds were collected from the related $J$. curcas plantation in the same year and their viability was tested using the floating method [57]. Seeds harvested and sown in the same year have a high germination rate (e.g. 93\% in Zimbabwe [58], 90\% in China [59], 97\% in Zambia (unpublished data Aklilu Negussie) and no seed dormancy has been reported, however, as J.curcas seeds are oily 
they cannot be stored for long [60]. After seed sowing, each seed position (one seed per position) was marked with a small metal nail to facilitate follow-up. Germination was monitored every 3 days for 36 days.

The results of the in situ germination experiment were analysed using two-way analysis of variance for each site to see the effect of different land use systems and seed sowing techniques on the final seed germination rate of $J$. curcas. Germination differences between the three sites were analyzed using non-parametric Scheirer-Ray-Hare two-way ANOVA. Analyses were performed using SPSS 17.0 for Windows (SPSS Inc., Chicago, IL). Significance levels to $P<0.05$ are presented.

\section{Results}

Spontaneous regeneration and seed dispersal risks of Jatropha curcas plantations to adjacent land use systems

Jatropha curcas fruiting and seeding occurs between August and October, thus in the rainy season. During this season, spontaneous regeneration around the perimeters of the $J$. curcas plantations at the three sites was very low. Only a single new seedling was recorded in one site (Tabou) about $20 \mathrm{~m}$ away from the boundary of $J$. curcas plantation. Spontanous regeneration was limited to within J. curcas plantations. The total seedling densities (+/- s.e.) in the plantations were $17500 \pm 4366 \mathrm{ha}^{-1}$ (Tabou), 12058 $\pm 2722 \mathrm{ha}^{-1}$ (Onliassan) and 10729 $3433 \mathrm{ha}^{-1}$ (Benaverou). There was no significant difference in seedling density between sites $\left(\chi^{2}=1.913 ; P=0.384\right)$. Based on the closest individual basic distance density estimator (individuals seedling $\mathrm{m}^{-2}$ ) around $J$. curcas live fences, we found $\leq 0.01$ seedlings $\mathrm{m}^{-2}$ in all monitored sites $\left(100,43,65,49,38,44,39\right.$, and 41 seedlings ha ${ }^{-1}$, respectively, for Yalle, Kayero, Neboun, Metio, Tabou, Léo, Zoro and Benaverou villages). About $70 \%$ of the seedlings were found close to the live fence $(<2.5 \mathrm{~m})$ and most of them were new, i.e. from the same year $(96 \%)$ (Table1).

(Insert table 1)

\section{Jatropha curcas seed dispersal experiment}

The average seed removal across all sites was 56\%. High seed removal was observed in Tabou site compared to 
Onliassan and Benaverou $\left(\chi^{2}=8.356, P=0.015\right)$. In each site there was also a seed removal difference among different land use systems except in Benaverou: $\chi^{2}=18.750, P<0.001$ (Tabou); $\chi^{2}=18.689, P<0.001$ (Onliassan); $\chi^{2}=1.750, P=0.248$ (Benaverou). In some land use systems, e.g. $J$. curcas field in Onliassan, up to $98 \%$ seed removal was observed (fig. 2). In Tabou and Benaverou, high seed removal was observed in fragmented woodlands. The mean seed survival time (+/- s.e.) was lower for seeds offered in the fragmented woodlands of Tabou (6 62 days) and Benaverou ( $9 \pm 2$ days) compared with open grasslands ( $10 \pm 3$ days for Tabou and $24 \pm 2$ days for Benaverou) and J. curcas plantations ( $14 \pm 3$ days for Tabou and $19 \pm 3$ days for Benaverou). In Onliassan, the reverse was observed with high seed survival time in the fragmented woodlands (18 \pm 3 days) compared with open grasslands ( $9 \pm 2$ days)

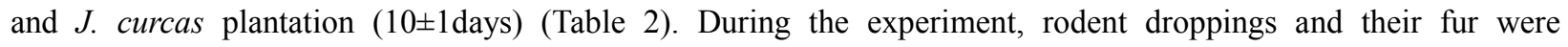
repeatedly observed around the seed offering depots. In addition some of the seeds were also observed to have been transported and destroyed by ants.

(Insert table 2)

(Insert fig. 2)

\section{Natural vs. artificial seed germination}

The germination experiments in different land use systems in Burkina Faso revealed an average germination rate of $11 \%$ where seeds were distributed on the soil surface, and $64 \%$ if buried artificially at $1-2 \mathrm{~cm}$ depth (fig. 3 ). In all sites, high average seed germination rate was observed for seeds sown $1-2 \mathrm{~cm}$ deep in the soil surface (up to $82 \%$ in some sites e.g. Benaverou) (fig. 3) $(P<0.001)$. Low mean seed germination was observed in Tabou site compared with the other two sites $(P<0.001)$. The interaction effects of site $\times$ land use system, site $\times$ seeding techniques, land use $\times$ seeding techniques and site $\times$ land use $\times$ seeding techniques were all insignificant. Based on germination comparisons for each site, seed sowing techniques showed significant difference at all sites, i.e. Tabou $(d f=1, F=$ 77.564, $P<0.001)$, Onliassan $(d f=1, F=83.503, P<0.001)$ and Benaverou $(d f=1, F=231.200, P<0.001)$. Land use systems showed significant differences in mean seed germination rates only for two of the sites: Tabou ( $d f=1, F$ $=11.615, P<0.001)$ and Benaverou $(d f=1, F=4.867, P=0.017)$ (fig. 3). The interaction effect of land use system $\mathrm{x}$ seed sowing technique was significant only for Tabou site $(d f=5, F=10.949 ; P<0.001)$. 
(Insert table 3)

\section{Discussion}

Jatropha curcas has been listed as "potential invader" or invasive in many countries [15,19,32-37,39,52,61,62]. However, critical analysis of the published literature [13], field observations by Negussie et al. [12] in Zambia and this study in Burkina Faso failed to find convincing evidence that it is having a significant impact on the surrounding land use systems. We did not observe significant invasiveness in any investigated site, neither from plantations nor from $J$. curcas live fences around homesteads and farms, some of which were more than 30 years old. This study indicated that primary fruit and seed dispersal mainly occurs by gravity and some presumably by humans. Many agricultural activities might contribute to the transportation of seeds and promote the intentional and accidental spread of $J$. curcas. A single seedling found in Tabou was also the result of these activities. The seedling resulted from fruits that had been unintentionally dumped in the trash pit which was located between $J$. curcas plantations and the groundnut field (Negussie A. personal observation). In addition, $J$. curcas fruits and seeds movement might be limited because of their large sizes, as primary seed dispersal through natural means is size and weight specific. $J$. curcas seeds are heavy $(0.6 \pm 0.1 \mathrm{~g})[12,13]$, and so unlikely to be wind-dispersed. The probability of Jatropha seeding in other land use systems through natural processes is minimal unless anthropogenic factors are involved.

Our seed dispersal experiment demonstrated that $J$. curcas can be dispersed by small mammals and arthropods, mainly by rodents and ants. In some sites, high secondary seed dispersal by small mammals was recorded (e.g. 98\% in J. curcas plantations at the Onliassan site and $89 \%$ in fragmented woodlands at the Tabou site). Seed removal was low in the Onliassan fragmented woodland compared with the other two fragmented woodlands (Tabou and Benaverou). The fragmented woodland in Onliassan was unprotected and adjacent to the residential area $(<1 \mathrm{~km})$. Hence, low seed removal could have resulted from low small mammal density in the fragmented woodland as a consequence of high human and livestock interference and frequent habitat disturbance. High seed removal in the protected $J$. curcas plantation, adjacent to the fragmented woodland from the same site could be as a result of low human and livestock interference in the protected woodland. 
The seeds of most known $J$. curcas accessions are highly toxic, including the African accessions, due to the presence of cursive ingredients such as curcin and phorbol esters $[63,64]$. Yet the current study demonstrated that $J$. curcas can be dispersed and eaten by small mammals. In Zambia, high $J$. curcas seed removal (up to 95\%) by rodents and shrews was reported [12]. The study of Negussie et al. [12] in Zambia identified $J$. curcas seed dispersers and predators by tracking them (e.g. through digging their burrows and examining whether droppings contained $J$. curcas seeds). Furthermore, their study validated the initial results by catching the animals alive while predating on $J$. curcas seeds and fruits using traps. Based on the tracking information and identification, that study identified four rodent species (Rattus rattus L., Thryonomys swinderianus Temminck, Saccostomus campestris Peters, Mastomys coucha Smith) and one elephant shrew species (Elephantulus intufi Smith). Furthermore, a seed searching experiment using a metal detector and digging up animal burrows showed that about $90 \%$ of seeds had been predated out of the total seeds retrieved. None of the retrieved intact seeds from predation had germinated because of deep burial down to $0.7 \mathrm{~m}$. Significant amounts of predated seeds husk were found in rodent and shrew burrows [12], thus these mammals can feed on $J$. curcas seeds. That study did not observe any dead animal in the burrows and this is surprising, given that these small mammals were feeding on toxic $J$. curcas seeds and this finding may warrant further investigation on their alimentary systems. Similarly, in Burkina Faso, J. curcas seed husks together with rodent droppings and their fur were repeatedly observed at the seed offering depots and around the depots. This high seed predation by rodents indicates that the recruitment probabilities of escaped seeds from $J$. curcas plantations to the surrounding terrestrial ecosystems are low.

Germination success is one of the preliminary steps in the colonization process of an invasive plant [65]. However, seed germination seemed difficult for J. curcas seeds under the existing natural circumstances whereby seeds drop on the surface and remain uncovered with soil. At all sites, we observed very low seed germination rates (between 3 and $14 \%$ ) for seeds sown on the soil surface without soil cover. Clearly, our results demonstrate that $J$. curcas seeds have specific germination requirements, such as being buried in the soil, and thus exposed seeds from decomposed fruits that have fallen onto the soil surface are unlikely to germinate. Similar results were found in Zambia, where approximately $4 \%$ seed germination rates for seeds spread on the surface of the soil were recorded [12]. Jatropha curcas invasiveness experiments in Zambia revealed that germination rates of naturally dropped fruits under the canopy were low (about 12\%), with a high probability of mortality in the subsequent dry season [12]. In plantations with more surface litter or where sheet soil erosion is common, dispersed J. curcas seeds may, by chance, become covered by soil or litter and then germinate. In the Tabou site, low seed germination was observed, probably due to the high precipitation in the area during that period. In addition, high seed removal was observed for 
seeds sown on the surface, probably by small mammals (e.g. rodents). At the end of the experiment, non-germinated seeds of those sown at 1-2 cm depth were uncovered randomly. Most of these seeds were found to be decayed, probably by fungi. The study of Heller [66], showed the presence of $J$. curcas seed fungi that can cause seed dampingoff (e.g. Phytophthora sp., Pythium sp. and Fusarium sp.). Jatropha curcas recruitment is also reportedly limited by high seedling mortality caused by pests and diseases [42, 67-71].

Furthermore, J. curcas produced very low seed yield per ha. At these sites in Burkina Faso, the average seed production for 4-year-old $J$. curcas trees was $0.3 \mathrm{~kg}$ (approximately 500 dry seeds) (about $0.5 \mathrm{t} \mathrm{ha}^{-1}$ ). The average seed yield harvested from a 2-year-old J. curcas plantation in Malawi was $<0.5 \mathrm{t} \mathrm{ha}^{-1}$ [72]. Similarly, the average yield from a 5-year-old poor-managed plantation in Zambia was $0.25 \mathrm{t} \mathrm{ha}^{-1}(0.15 \mathrm{~kg}$ seed per tree, approximately $<$ 400 seeds per tree) at $2 \times 3 \mathrm{~m}$ plant spacing. In addition to low seed yield, viable seed dispersal and colonization are no guarantee for recruitment [65]. Where seeds arrive and the conditions where the seedlings are emerging are important. In the study region, $J$. curcas fruits fall then rot under the parent plant in the rainy season. In the following dry season, it has been observed that termites and true bugs can then attack the fruits and expose the seeds. Subsequently, black ants can crack the seed coats to feed on the oil (Negussie A. personal observation), and this is likely to reduce seed fecundity. Even if we observed 10,000 to 17,000 seedlings ha ${ }^{-1}$ in some sites, the survival rate of the seedlings was very low. In Zambia, post-germination seedling mortality probability was high, e.g., up to $83 \%$ [12]. Similarly, high seedling mortality has been observed in Burkina Faso. We did not observe any old seedlings in 4-year-old plantations during our assessment, which indicates low seed bank survival from the previous seasons. The primary cause of seedling mortality was the consumption of the entire soft shoot and leaves by insects such as grasshoppers, stem-feeding weevils, flea beetles of the genus Aphtona and sometimes the common bush fires in the dry seasons. All these conditions limit J. curcas regeneration and spreading potential in the assessed sites.

In conclusion, the results of this experiment on invasiveness in Burkina Faso support those found in a previous study by Negussie et al. [12] in Zambia, that also failed to find any convincing evidence of the spread of J. curcas. Further discussions with local experts and farmers also corroborated the lack of evidence for $J$. curcas being invasive in the Sahel region, despite decades of presence in the region as live fences. However, more studies are needed in different agroecozones and habitats to validate the current study. Furthermore, exotic plants often show a long lag phase 
before becoming invasive [73] and the rapidity at which an alien plant becomes invasive is known to be related to propagule pressure, i.e. the amount of seeds released in the environment [74]. Considering the enormous increase in $J$. curcas plantations in Africa in recent years, it is necessary to remain vigilant and develop better management interventions for minimising risk in agro-fuel development in Africa. The low numbers found (on average, about 4 to 7 propagules under a single tree canopy in our case for $J$. curcas trees planted at $2 \mathrm{~m} \times 2 \mathrm{~m}$ spacing) and the high seedling mortality probability observed (about $>80 \%$ ) is unlikely to lead to a high risk of invasion in climates similar to the study region. However, several human activities during the cultivation process may have played a significant role in the transportation and spread of $J$. curcas. Indeed, if the plant is not well managed, the propagule production would reach between 30 and 60 seedlings per tree canopy, which might increase risk. Therefore, simple management practices such as timely and complete fruit harvesting, frequent weeding and safe transportation of seeds and planting materials could avoid invasion risks of $J$. curcas.

\section{Acknowledgements}

This research was funded by the ERA ARD Jatrophability project and supported by KU Leuven, VLIR-UOS, and

Fondation Fasobiocarburant, Burkina Faso. Lindsey Norgrove is supported by the SNSF (Swiss National Science Foundation) through a Marie Heim-Vögtlin research fellowship. World Agroforestry Center (ICRAF), Addis Ababa, Ethiopia office is highly acknowledged for hosting Aklilu Negussie as temporary staff during the preparation of the manuscript. The authors would like to thank Fondation Fasobiocarburant staffs in Léo. The authors also thank ADECIA for their financial assistance through the Fasobiocarburant Foundation'. Special thanks go to Onliassan, Benaverou, Tabou, Yalle, Metio, Kayero, Zoro, Léo and Neboun farmers and agricultural extension workers. We would like to thank two anonymous reviewers for their helpful comments and suggestions

\section{References}

1. Lima M, Pedrozo E, Vilela Junqueira NT (2008) A new paradigm on trade-off biodiesl food: the perennial oleaginous palm tree. simposio.cpac.embrapa.br 1: 1-8

2. Danielsen F, Beukema H, Burgess ND, Parish F, Brühl C.A, Donald PF, et al. (2009) Biofuel plantations on forested lands: double jeopardy for biodiversity and climate. Conserv Biol 23: 348-358

3 International Energy Agency (IEA) (2012) $\mathrm{CO}_{2}$ Emissions from fuel combustion. IEA, Paris, France, 125 pp 
4. International Energy Agency IEA (2006) Key world energy statistics. Paris, France. Available at: http://www.iea.org/Textbase/nppdf/free/2006/Key2006.pdf

5. IUCN (2009) Guidelines on Biofuels and Invasive Species. Gland, Switzerland, IUCN, 20pp

6. Santos M, Freitas R, Crespí AL, Hughes SJ, Cabral JA (2011) Predicting trends of invasive plants richness using local socio-economic data: an application in North Portugal. Environ Res 111(7): 960-976

7. Van Wilgen BW, Reyers B, Le Maitre DC, Richardson DM, Schonegevel L (2008) A biome-scale assessment of the impact of invasive alien plants on ecosystem services in South Africa. J Environ manage 89(4): 336-49

8. Folke C, Coulding J, Berket F (2003) Synthesis: building resilience and adaptive capacity in social-ecological systems. In: Berkes F, Colding J, Folke C (eds). Navigating social-ecological systems: building resilience for complexity and change, Cambridge University Press, p. 352-387

9. Lake JC, Leishman MR (2004) Invasion success of exotic plants in natural ecosystems: the role of disturbance, plant attributes and freedom from herbivores. Biol Cons 117: 215-226

10. DiTomaso JM, Barney JN, Fox A (2007) Biofuel Feedstocks: The Risk of future invasions. Council for Agricultural Science and Technology. Commentary; QTA 2007-1

11. DiTomaso JM, Reaser JK, Dionigi CP, Doering OC, Chilton E, Schardt JD, Barney JN (2010) Biofuel vs bioinvasion: seeding policy priorities. Environ Sci Technol 44: 6906-6910

12. Negussie A, Achten WMJ, Aerts R, Norgrove L, Sinkala T, Hermy M, Muys B (2013) Invasiveness risk of the tropical biofuel crop Jatropha curcas L. into adjacent land use systems: from the rumors to the experimental facts. Glob Change Biol Bioenergy 5: 419-430

13. Negussie A, Achten WMJ, Norgrove L, Hermy M, Muys B (2013) Invasiveness risk of biofuel crops using Jatropha curcas L. as a model species. Biofuel bioprod biorefin 7:485-498

14. Dawson W, Burslem DFRP, Hulme PE (2009) The suitability of weed risk assessment as a conservation tool to identify invasive plant threats in East African rainforests. Biol Cons 142: 1018-1024

15. Gordon DR, Tancig KJ, Onderdonk DA, Gantz CA (2011) Assessing the invasive potential of biofuel species proposed for Florida and the United States using the Australian weed risk assessment. Biomass Bioenergy 35: 74-79

16. Landis WG (2004) Ecological risk assessment conceptual model formulation for nonindigenous species. Risk Anal 24: 847 
17. Andersen MC, Ewald M, Northcott J (2005) Risk analysis and management decisions for weed biological control agents: Ecological theory and modeling results. Biol Control 35: 330-337

18. Pheloung PC, Williams PA, Halloy SR (1999) A weed risk assessment model for use as a biosecurity tool for evaluating plant introductions. J Environ Manage 57: 239-251

19. Daehler CC, Denslow JS, Ansari S, Kuo HC (2004) A risk-assessment system for screening out invasive pest plants from Hawaii and other pacific islands. Conserv Biol 18: 360-368

20. Flory SL, Lorentz KA, Doria R Gordon DR, Sollenberger LE (2012) Experimental approaches for evaluating the invasion risk of biofuel crops. Environ Res Lett 7: 045904

21. Ives AR, Schellhorn NA (2011) Novel pests and technologies: risk assessment in agroecosystems using simple models in the face of uncertainties. Curr Opin Environ Sustainability 3: 100-104

22. Sheppard AW, Gillespie I, Hirsch M, Begley C (2011) Biosecurity and sustainability within the growing global bioeconomy. Curr Opin Environ Sustainability 3: 4-10

23. Achten W, Verchot L, Franken Y, Mathijs E, Singh V, Aerts R, Muys B (2008) Jatropha bio-diesel production and use. Biomass Bioenergy 32: 1063-1084

24. Chhetri AB, Tango MS, Budge SM, Watts KC, Islam MR (2008) Non-edible plant oils as new sources for biodiesel production. Int J Mol Sci 9: 169-80

25. Makkar HPS, Becker K (2009) Jatropha curcas, a promising crop for the generation of biodiesel and valueadded coproducts. Eur J Lipid Sci Technol 111: 773-787

26. Corro G, Tellez N, Ayala E, Marinez-Ayala A (2010) Two-step biodiesel production from Jatropha curcas crude oil using $\mathrm{SiO} 2 \cdot \mathrm{HF}$ solid catalyst for FFA esterification step. Fuel 89: 2815-2821

27. Brittaine R, Lutaladio N (2010) Jatropha: a Smallholder Bioenergy Crop. The Potential for Pro-Poor Development. Integrated Crop Management Vol. 8. FAO, Rome, Italy

28. Nassiré Derra A, Yélémou B, Sanon KB, Hilou A, Millogo/Rasolodimby J, and Hien V (2013) Management patterns of Jatropha curcas: Impact on the microbial and the mycorrhizial biomasses in different phyto geographic zones of Burkina Faso. Adv Appl Sci Res 4(6):256-267

29. Ayuk ET (1997) Adoption of Agroforestry Technology: The Case of Live Hedges int he Central Plateau of BurkinaFaso. Agr Syst 54(2):189-206 
30. Henning RK. (2007) Jatropha curcas L. In: van der Vossen HAM \& Mkamilo GS (Editors). Prota 11(1): Medicinal plants/Plantes médicinales 1. PROTA, Wageningen, Netherlands

31. Misra M, Misra AN (2010) Jatropha: The biodiesel plant biology, tissue culture and genetic transformation - A review. Int J Pure Appl Sci Technol 1: 11-24

32. PIER (2008) Pacific Islands Ecosystems at Risk. USA, Institute of Pacific Islands Forestry. http://www.hear.org/pier/index.html, accessed on 28 March 2012

33. Crosti R, Cascone C, Cipollaro S (2010) Use of a weed risk assessment for the Mediterranean region of Central Italy to prevent loss of functionality and biodiversity in agro-ecosystems. Biol Invasions 12:1607-1616

34. Global Invasive Species Programme (GISP) (2008) Biofuels run the risk of becoming invasive species. Available at: http://www.issg.org/pdf/publications/GISP/Resources/BiofuelsReport.pdf

35. Royal Botanic Gardens Sydney (2008) Australia's Virtual Herbarium. Australia's Virtual Herbarium. Sydney, Australia: Royal Botanic Gardens. http://avhtas.tmag.tas.gov.au/

36. Wells MJ, Balsinhas VM, Joffe H, Engelbrecht VM, Harding G, and Stirton CH (1986) A Catalogue of Problem Plants in Southern Africa, incorporating The National Weed List of South Africa, Memoirs of the Botanical Survey of South Africa No. 53. Botanical Research Institute, Pretoria, South Africa

37. USDA-NRCS (2008) The PLANTS Database. Baton Rouge, USA: National Plant Data Center. Available at http://plants.usda.gov

38 Caius JF (1986) The Medicinal and Poisonous Plants of India. Scientific Publishers, Jodhpur, India

39. Meyer JY (2000) Preliminary review of the invasive plants in the Pacific islands (SPREP Member Countries). In: Sherley G, (.ed.). Invasive species in the Pacific: a technical review and draft regional strategy, South Pacific Regional Environment Programme, Samoa

40. Flora of China Editorial Committee (2007) Flora of China Web. Cambridge, USA: Harvard University Herbaria. available at: $\underline{\text { http://flora.huh.harvard.edu/china }}$

41. Missouri Botanical Garden (2008) Tropicos database. St Louis, USA: Missouri Botanical Garden. Available at http://www.tropicos.org

42. Spaan W, Bodnár F, Idoe O, De Graaff J (2004) Implementation of contour vegetation barriers under farmer conditions in Burkina Faso and Mali. Quart J Int Agri 43: 21-38 
43. Wani SP, Osman M, Emmanuel DS, Sreedevi, TK (2006) Improved livelihoods and environmental protection through biodiesel plantations in Asia. Asian Dev Rev 8: 11-29

44. Gordon DR, Onderdonk DA, Fox AM,and, Stocker RK (2008) Consistent accuracy of the Australian weed risk assessment system across varied geographies. Diversity and Distributions 14: 234-242

45. Peel MC, Finlayson BL, \& McMahon TA (2007) Updated world map of the K"oppen-Geiger climate classification. Hydrology \& Earth System Sciences 11: 1633-1644

46. Seidler TG, and Plotkin JB (2006) Seed dispersal and spatial pattern in tropical trees. PLoS Biol 4:2132-2137

47. Hannan-Jones M, and Csurhes S (2008) Pest Plant Risk Assessment Physic Nut, PR 08-3681. Department of Primary Industries and Fisheries, Queensland Government, Queensland, Australia

48. Sahoo NK., Kumar A, Sharma S, Naik SN (2009) Interaction of Jatropha Curcas Plantation with Ecosystem. Proceedings of international conference on energy and environment March 19-21. Enviroenergy, ISSN: 20703740, pp 666-671

49. Subramanyam K, Rao DM, Devanna N, Aravinda A, and Pandurangadu V (2010) Evaluation of genetic diversity among Jatropha curcas L. by RAPD analysis. Indian J Biotechnol 9:283-288

50. Wahl N, Hildebrandt T, Moser C, Lüdeke-Freund F, Averdunk K, Bailis R, et al. (2012) Insights into Jatropha Projects Worldwide, Key Facts \& Figures from a Global Survey. Centre for Sustainability Management (CSM), www.leuphana.de/en/institute/csm, ISBN 978-3-942638-28-9

51. Davis AD, Cousens RD, Hill J, Mack RN, Simberloff D, and Raghu S (2014). Screening bioenergy feedstock crops to mitigate invasion risk. Front Ecol Environ; doi:10.1890/090030

52. Quinn LD, Barney JN, McCubbins JSN, and Bryan Endres AB (2014) Navigating the "Noxious" and "Invasive" Regulatory Landscape: Suggestions for Improved Regulation. BioScience 63(2):124-131.

53. Thompson K and Davis MA (2011) Why research on traits of invasive plants tells us very little. Trends Ecol Evol 26:155-156.

54. Negussie A, Achten WMJ, Verboven HAF, Hermy M \& Muys B (2014) Floral display and effects of natural and artificial pollination on fruiting and seed yield of the tropical biofuel crop Jatropha curcas L. Glob Change Biol Bioenergy 6: 210-218

55. Engeman RM, Sugihara RT, Pank LF, Dusenberry WE (1994) A composition of plotless density estimators using Monte-Carlo simulation. Ecology 75: 1769-1779 
56. Aerts R, Maes WH, November E, Negussie A, Hermy M, Muys B 2006 Restoring dry Afromontane forest using bird and nurse plant effects: direct sowing of Olea europaea ssp. cuspidata seeds. Forest Ecol Manag 230: $23-31$.

57. Schmidt, LH (2007) Tropical forest seeds. Springer-Verlag Berlin Heidelberg, New York, 409 p

58. Jepsen JK, Henning RK and Nyathi B (2012) Generative propagation of Jatropha curcas L. on Kalahari Sand. Available at: http:// www.jatropha.pro/generative\%20propagation.htm [February 23, 2012]

59. Meng Ye, Caiyan Li, Francis G and Makkar HPS (2009) Current situation and prospects of Jatropha curcas as a multipurpose tree in China. Agrofor Syst 76:487-497

60. Deng ZJ, Cheng HY and Song SQ (2005) Studies on Jatropha curcasseed. Acta Bot Yunnanica 27:605-612

61. Space JC, Flynn T (2001) Report to the Kingdom of Tonga on invasive plant species of environmental concern. USDA Forest Service, Pacific Southwest Research Station, Institute of Pacific Islands Forestry.

62. Lauren D. Quinn, Doria R. Gordon, Aviva Glaser, Deah Lieurance, S. Luke Flory (2014) Bioenergy Feedstocks at Low Risk for Invasion in the USA: a "White List" Approach.Bioenerg Res: DOI $10.1007 / \mathrm{s} 12155-014-9503-\mathrm{z}$

63. Makkar HPS, Becker K, Sporer F, Wink M (1997) Studies on nutritive potential and toxic constituents of different provenances of Jatropha curcas. J Agric Food Chem 45: 3152-3157

64. Li CY, Devappa RK, Liu JX, Lv JM, Makkar HPS, Becker K (2010) Toxicity of Jatropha curcas phorbol esters in mice. Food Chem Toxicol 48: 620-625

65. Greenberg CH, Smith LM, Levey DJ (2011) Fruit fate, seed germination and growth of an invasive vine - an experimental test of 'sit and wait' strategy. Biol Invasions 3: 363-372

66. Heller J (1992) Studies on genotypic characteristics and propagation and cultivation methods for physic nuts (Jatropha curcas L.). Kovac, Hamburg

67. Singh NS (2008) Anti termite activity of Jatropha curcas Linn. biochemicals. J Appl Sci Environ Manage 12: $67-69$

68. Jimu L, Nyakudya IW (2009) Establishment and early field performance of Jatropha curcas L at Bindura. Sustain Dev 10: 445-469 
69. Ramkat R, Calari A, Maghuly F, Laimer M (2011) Occurrence of African cassava mosaic virus (ACMV) and East African cassava mosaic virus-Uganda (EACMV-UG) in Jatropha curcas. BMC Proceedings 5 (Suppl 7): P93 doi:10.1186/1753-6561-5-S7-P93

70. Rao CS, Kumari MP, Wani SP, Marimuthu S (2011) Occurrence of black rot in Jatropha curcas L. plantations in India caused by Botryosphaeria dothidea. Curr Sci 100: 1547-1549

71. Prabhakar M, Prasad YG, Rao GR, Venkateswarlu B (2012) A new record of longicorn beetle, Acanthophorus rugiceps, from India as a root borer on Physic nut, Jatropha curcas, with a description of life stages, biology, and seasonal dynamics. J insect sci 12: 141. http:/www.insectscience.org/12.114

72. Negussie A (2013) Regeneration ecology of Jatropha curcas L. in Africa: implications for its biofuel production and invasiveness. Doctoral thesis, Faculty of Bioscience Engineering, KU Leuven, Belgium. 166 pp. Available on https://lirias.kuleuven.be/handle/123456789/410001

73. Sakai AK, Allendorf FW, Holt JS, Lodge DM, Molofsky J, With KA, et al. (2011) The population biology of invasive species. Annu Rev Ecol Syst 32:305-332

74. Lockwood JL, Cassey P, Blackburn T (2005) The role of propagule pressure in explaining species invasions. Trends Ecol Evol 20: 223-228 


\section{Table caption}

Table 1 Seedling occurrence in percent and distance away from the live fence of $J$. curcas in Burkina Faso, ( $\mathrm{N}=$ 868).

Table 2 Breslow (Generalized Wilcoxon) pairwise comparisons for J. curcas seed survival time at different land use systems. Land use types: J. curcas plantation (JCP) open grassland (OGL) and Fragmented woodland (FWL). 
Table 1

\begin{tabular}{ll}
\hline Seedling distance $(\mathrm{m})$ & Total seedling $(\%)$ \\
\hline$<2.5$ & 70 \\
$2.5-5$ & 22 \\
$5-10$ & 7 \\
$>10$ & 1 \\
\hline Note: Number of villages observed 8, total length of the live fence assessed $3.8 \mathrm{~km}$
\end{tabular}


Table 2

\begin{tabular}{|c|c|c|c|}
\hline Sites & Land use systems & $\mathrm{BW}=\chi^{2}$ & $P$ \\
\hline \multirow[t]{3}{*}{ Tabou } & $\mathrm{FWL} \times \mathrm{OGL}$ & 1.167 & 0.683 \\
\hline & $\mathrm{FWL} \times \mathrm{JCP}$ & 0.956 & 0.328 \\
\hline & $\mathrm{OGL} \times \mathrm{JCP}$ & 0.192 & 0.662 \\
\hline \multirow[t]{3}{*}{ Onliassan } & $\mathrm{FWL} \times \mathrm{OGL}$ & 4.348 & $0.037 *$ \\
\hline & $\mathrm{FWL} \times \mathrm{JCP}$ & 10.583 & $0.001 *$ \\
\hline & $\mathrm{OGL} \times \mathrm{JCP}$ & 1.840 & 0.175 \\
\hline \multirow[t]{3}{*}{ Benaverou } & $\mathrm{FWL} \times \mathrm{OGL}$ & 15.771 & $<0.001 * *$ \\
\hline & $\mathrm{FWL} \times \mathrm{JCP}$ & 4.456 & $0.035^{*}$ \\
\hline & $\mathrm{OGL} \times \mathrm{JCP}$ & 1.438 & 0.230 \\
\hline
\end{tabular}




\section{Figure caption}

Figure 1 Monthly rainfall for Tabou and Léo areas in the Sisili province from January 2012 -December 2012.

Figure 2 Seed removal percentage calculated as mean percentage for 16 depots per land use system with 10 seeds: (०) J. curcas plantation, ( $\boldsymbol{\Delta})$ open grassland and $(\times)$ fragmented woodland in Sissili province, Burkina Faso. The error bars represent the standard error (s.e.).

Figure 3 Effect of different land use types (J. curcas plantation, fragmented woodland and open grassland) and seed sowing techniques (seeds sown buried 1-2 cm (०) and seeds sown surface $(\times)$ ) on seed germination percentage (mean percent \pm s.e.) of $J$. curcas in 3 individual sites of Sissili province, Burkina Faso. 




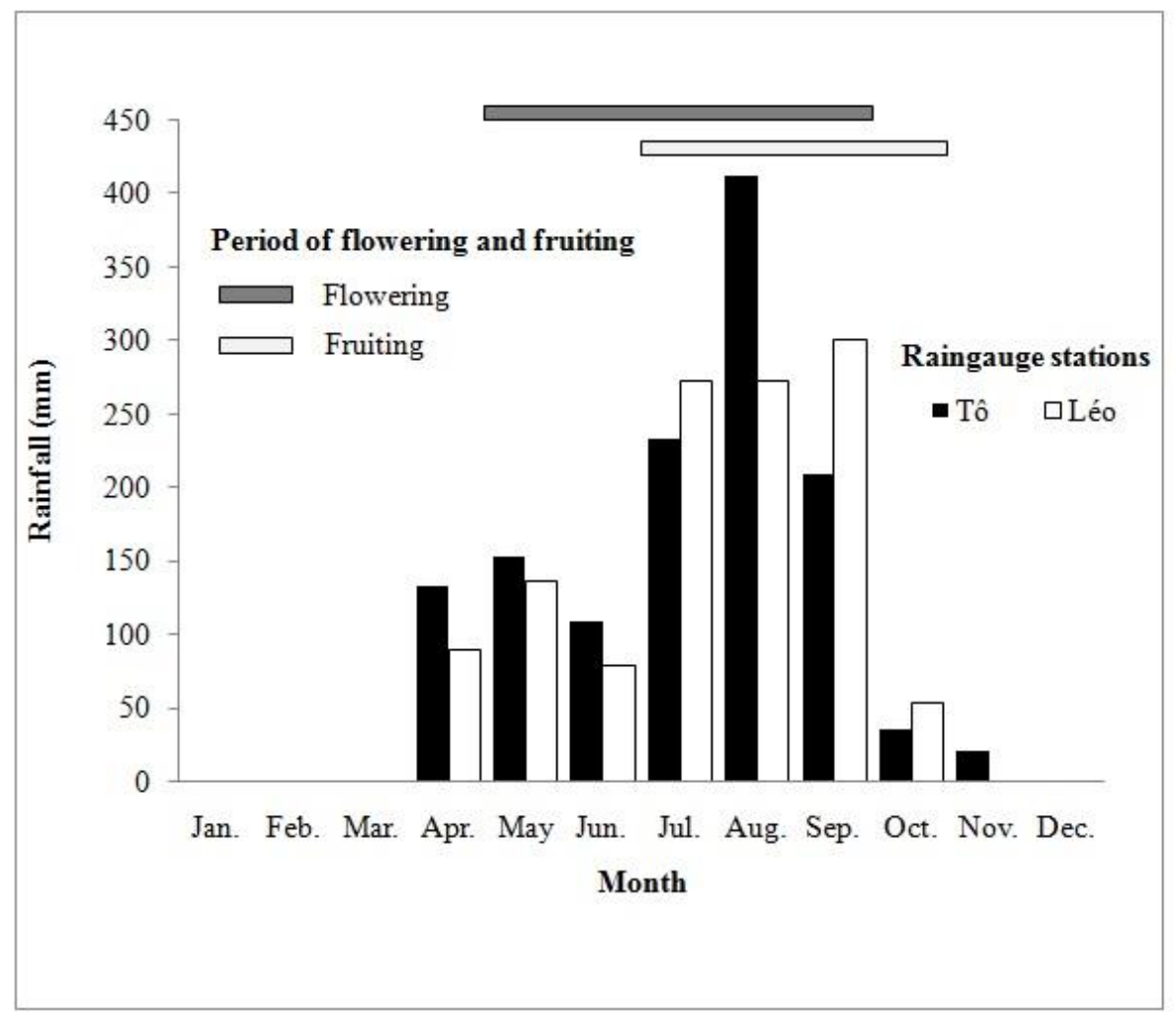



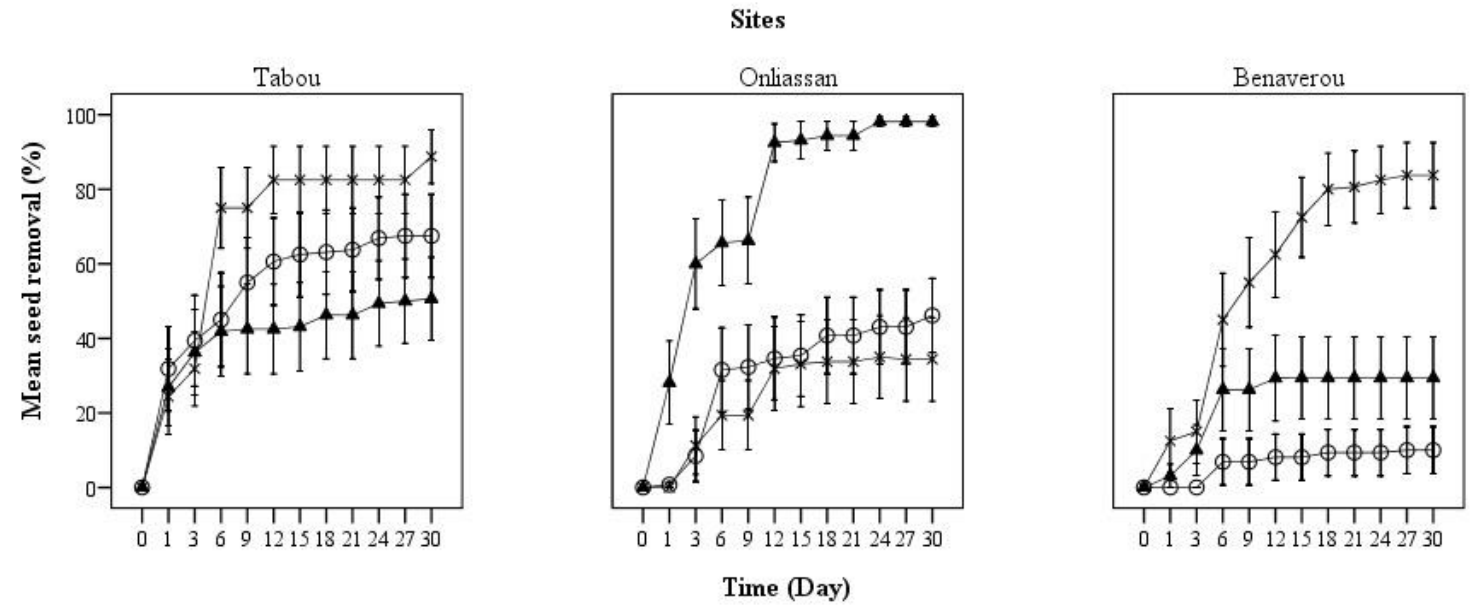


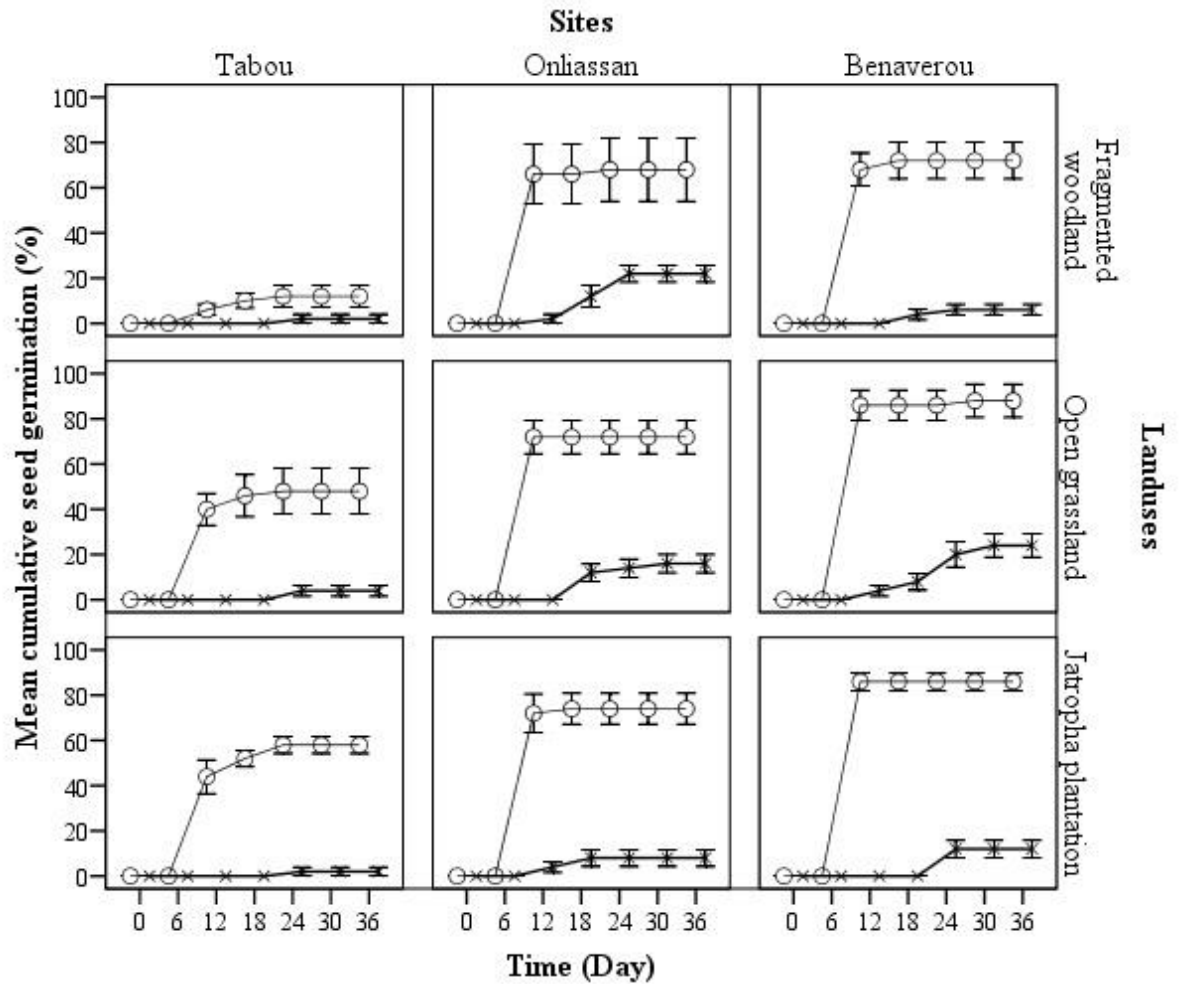


